\title{
FOOD PORN: DILEMA EKSOTISME DARI SEBUAH MAKNA MAKANAN DALAM KERAMIK EKSPRESI
}

\author{
Dyah Retno Fitriani *)
}

\begin{abstract}
ABSTRAK
Food porn dalam dua sampai tiga tahun terakhir ini terhitung sejak 2014 menjadi sangat viral disosial media. Food porn merupakan hashtag yang dibuat di Instagram untuk menandai foto yang menampilkan makanan dengan teknik photography yang menampilkan kelezatan makanan tersebut dari dekat. Food porn menjadi sebuah tema yang diangkat dalam pembuatan karya seni keramik ekspresi ini dengan mengambil objek donat dan bulu babi yang juga mengkhawatirkan keadaannya akibat eksploitasi yang terlalu berlebihan sehingga keberadaannya hampil punah. Kedua objek tersebut menjadi perwakilan yang akan digabungkan dengan bentuk-bentuk coral. Kelautan Indonesia yang sangat luas dan memiliki keindahan coral yang sangat luar biasa menjadikan Indonesia sebagai target spot penyelaman paling indah didunia, sama halnya seperti yang dikatakan Kall Muller (1999: 15) "The Island of Indonesia spread in a wide arc, more than 5.000 kilometer long, from mainland Southeast Asia to Papua New Guinea. Dotted with volcanoes, covered with thrick tropical vegetation and bright green rice fields, and surrounded by coral reefs, the Indonesian archipelago is one of the world's most beautiful places". Wacana-wacana ini menjadi latar belakang paling mendasar yang kemudian akan diolah dan dijadikan bahan ide pembuatan keramik ekspresi.

Pembuatan karya seni ini dimulai dari pengeksplorasian wacana, bentuk, dan konsep yang kemudian diolah dan dijadikan sketsa rancangan. Selanjutnya untuk mewujudkan karya seni, pemilihan bahan menjadi aspek paling penting untuk kelangsungan prosesnya. Pembuatan karya ini menggunakan tanah stoneware Sukabumi dan Pacitan yang dicampur dengan perbandingan 1:1 untuk mendapatkan kekuatan dan warna yang cerah. Kemudian pengerjaan selanjutnya adalah membuat model yang akan dibuat untuk cetakan. Cetakan dibuat dengan gpsum dan dilakukan slip casting dengan tanah yang sudah diolah sebelumnya. Pendekorasian dilakukan dengan teknik krawang, pilin dan pinch untuk selanjutnya dikeringkan dan dibakar biskuit. Selanjutnya glasir dicampur dengan stain dan diaplikasikan kedalam badan keramik dengan teknik semprot menggunakan spraygun dan kompresor lalu dibakar glasir dengan suhun $1200^{\circ}$ C. Penciptaan karya seni ini juga diperkuat dengan beberapa teori seperti : teori penciptaan, ekspresi dan art and synesthesia.

Hasil karya ini merupakan sebuah perspektive challenging dari seniman untuk dipublikasikan kepada audience. Penguatan teori dengan art and synesthesia merupakan sebuah cara untuk membuktikan bahwa karya seni ini tidak hanya bisa dinikmati dengan satu indera saja, namun keterikatan antara atu indera dengan indera lainnya. Sehingga apabila hal ini secara maksimal mampu ilakukan kemudian dapat diterapkan sebagai media untuk terapi penyembuhan trypophobia karena sedikit banyak tekstur yang diaplikasikan merupakan perwujudan dari trypophobia.
\end{abstract}

\footnotetext{
* Dyah Retno Fitriani, Mahasiswa Program Pascasarjana Institut Seni Indonesia Yogyakarta
} 


\begin{abstract}
Since 2014, foodporn phenomena became famous and going viral on social media. Food porn is one of Instagram's hashtag that showing a close up mesmerizing food photography. Foodporn being adapted as a theme for this expression ceramics artwork with doughnut and almost extinct sea urchins as the main objects. The condition of sea urchins are very endanger because of excessive exploitation. Those two objects will be represent as a coral shape.

Indonesia became the most huge maritime nation that having a billion beautiful coral. Indonesia became a most beautiful diving spot, Kall Muller said (1999:15) "The Island of Indonesia spread in a wide arc, more than 5.000 kilometer long, from mainland Southeast Asia to Papua New Guinea. Dotted with volcanoes, covered with thrick tropical vegetation and bright green rice fields, and surrounded by coral reefs, the Indonesian archipelago is one of the world's most beautiful places". The text above write as fundamental background and basic idea to making this expression ceramics artwork.

This artwork start with discourse exploration, shape, and concept that elaborate into sketch design. On second step, material become the most important aspect to creating this artwork. This artwork utilize a Sukabumi and Pacitan's stoneware soil. It mixing with ratio 1:1 to have a strong and bright color. Third step is making a model for the mold. Mold made by gypsum and slip casting with a soil mixing. Decorating conducted with cire perdue technique, coil, and pinch and then be drained and bisque firing. On the next step, glaze will be mixed with stain and applied in to ceramic's body with a spraygun and compressor. Then glaze burned with $1200^{\circ} \mathrm{C}$. This artwork also strengthed by some theory, namely; the theory of creation, expression, art and synesthesia.

This artwork is a form of artist's challenging perspective for being publish to the audience. Strengthed by art and synthesia theory, this artwork is one of the way to prove that artwork can be felt not only one sense, but connection between one with another senses. Thereby, if this artwork can be applied maximally, it might have a chance to be a new theraphy methodology for a trypophobia healing, because most texture that applied in this artwork is the embodiment of trypophobia.
\end{abstract}

Keyword : Foodporn, Expression Ceramics, Texture

\section{PENDAHULUAN}

Perkembangan teknologi komunikasi dan informasi yang berkembang pesat diikuti dengan kecanggihan gadget, membuat manusia sekarang tidak bisa lepas darinya. Keduanya menjadi kebutuhan sehari-hari guna mempermudah kegiatan, komunikasi, saling bertukar data, dan menjadi life style masa kini. Instagram misalnya menjadi salah satu aplikasi paling terpopular masa kini yang digunakan berbagai kalangan, sehingga foto, video dapat diupload dengan menggunakan caption, tag, dan hashtag lalu dibagikan hingga berbagai manusia dari berbagai belahan bumi manapun dapat melihatnya, saling mengenal, dan bertukar informasi dalam sekian detik saja. 
Berbagai kegiatan bisa di share di Instagram, baik itu karya seni, outfit of the day berupa style yang digunakan anak muda, bahkan restoran dan makanan yang mereka kunjungi menjadi sangat viral dan menjadi sebuah fenomena sosial. Fenomena sosial yang bertajuk Food porn, kemudian melatarbelakangi penulis menjadi topik pembahasam yang akan diekspresikan kedalam karya seni dengan media keramik. Food porn di Instragram dijadikan sebuah hashtag yang menampilkan berbagai foto dengan tampilan makanan-makanan yang telihat lezat dan membuat indera pengelihatan menangkapnya hingga mempengaruhi rasa lapar. Makanan yang diambil dengan sangat fotogenic ini juga dilakukan berbagai kalangan yang ingin memamerkan bagaimana kegiatan mereka, restoran mana yang mereka kunjungi, dan makanan apa yang mereka makan. Disisi lain kegiatan ini merupakan sebuah ajang untuk mendapat pengakuan dari orang lain, sehingga mereka berlomba-lomba untuk mengambil foto sebagus mungkin yang didukung dengan caption, hashtag, check in, tag dan lain sebagainya sehingga mendapat banyak love dari pengguna instagram lainnya.

Fenomena sosial Food porn yang menjadi topik dalam pembuatan karya ini, kemudian diolah oleh menulis untuk dijadikan karya keramik ekspresi dengan menggabungkanya dengan bentuk-bentuk teksur biota laut. Mengingat keastistikan dari segi bentuk, warna dan kekayaan laut Indonesia yang luar biasa, kemudian biota laut diangkat untuk mendukung karya seni keramik ekspresif ini. Indonesia merupakan salah satu negara yang disebut sebagai salah satu negara yang sangat indah di dunia karena dikelilingi oleh gunung berapi, sawah dan coral serta biota laut yang menghiasi sepanjang kepulauan Indonesia. Hal ini senada dengan apa yang dikatakan Kall Muller (1999: 15) "The Island of Indonesia spread in a wide arc, more than 5.000 kilometer long, from mainland Southeast Asia to Papua New Guinea. Dotted with volcanoes, covered with thrick tropical vegetation and bright green rice fields, and surrounded by coral reefs, the Indonesian archipelago is one of the world's most beautiful places".

Coral dan biota laut di sepanjang kepulauan Indonesia menjadi primadona bagi para penyelam dari berbagai penjuru dunia. Spot penyelaman yang paling dicari di Indonesia berada di Sumatera, Bali, Lombok, Komodo Island, Maumere Flores, Sumba, Kupang, Sulawesi, Kalimatan Timur, Ambon, Banda, dan Papua. Setiap spot mempunyai keunikan masing-masing, baik dari coral atau biota lautnya. Seperti yang ada di Raja Ampat Papua, batu karang yang dapat ditemukan berbentuk seperti dinding yang vertikal, goa bawah laut, danau, dan karang yang seperti panggung-panggung yang menurut beberapa penyelam yang sudah berkeliling dunia hanya ada di Indonesia. Dan setiap tempat mempunyai tipikal karangnya masing-masing yang tentunya akan menjadi cirikhas wisata penyelaman bawah laut yang patut kita banggakan dan lestarikan.

Keindahan coral dan biota laut tidak hanya menarik perhatian para penyelam, namun juga penulis dalam berkarya. Bentukbentuk karyanya mengadopsi dari apa yang ada dilaut dan digabungkan dengan kegelisahan lain yang dirasakannya. Dalam proses berkarya penulis menggunakan media keramik berglasir. Kegeliatan tanah liat membuat media ini fleksibel untuk dibentuk, walaupun beberapa kendala kadang dialami seperti keretakan, pecah, atau meledak dalam pembakaran. Dalam pengertian harafiahnya menurut kamus bahasa Indonesia keramik adalah tanah liat yang dibakar yang dicampur dengan mineral lain (Moeliono, 1998: 423). Walaupun dalam proses pembentukan prinsip nya hampir sama seperti patung, yang membedakan keramik dengan patung adalah dari segi material yang harus menggunakan tanah dengan daya bakar suhu diatas $900^{\circ} \mathrm{C}$, pembentukan yang menuntut bagian dalam harus berongga, 
dan melalui proses pembakaran. Dalam mitologi Yunani, keramik berasal dari kata keramos yang berarti periuk atau belanga yang juga merupakan nama dewa pelindung dari para pembuat kerajinan tanah liat atau keramik, dimana keramos merupakan putra dari Dewa Baccus dan Dewi Ariadne (Astuti, 1997:1).

Berbagai masalah melatar belakangi pencipaan karya seni ini, maka untuk membatasi disimpulkanlah dua rumusan masalah yaitu Bagaimana proses penciptaan karya seni keramik ekspresi dengan ide Food porn dan bagaimana konsep pencipaan dari ide Food porn untuk diwujudkan dalam keramik ekspresi. Adapun tujuan dari pencipaan karya ini selain untuk mengeksplorasi berbagai wacana viral yang ada disosial media, juga untuk memvisualkan hasil eksplorasi yang akan diwujudkan menjadi sebuah karya keramik ekspresi beserta konsep dan proses perwujudannya.

\section{METODE}

Keramik menurut kamus bahasa Indonesia adalah : "Tanah liat yang dibakar, dicampur dengan mineral lain : barangbarang tembikar (porselen) " (Moeliono, 1998: 423). Sedangkan menurut Astuti (1997:1), "Kata keramik berasal dari bahasa Yunani 'keramos' yang berarti periuk atau belanga yang terbuat dari tanah yang melalui pembakaran suhu tinggi “. Ditelusuri lebih jauh, keramos merupakan nama dari salah satu dewa Yunani. "Dalam mitologi Yunani, keramos merupakan dewa pelindung dari para pembuat kerajinan tanah liat atau keramik. Keramos adalah putra dari Dewa Baccus dan Dewi Ariadne “ (Astuti, 1997:1).

Pada mulanya keramik hanya sebagai bahan kerajinan namun seiring dengan perkembangannya, keramik mulai dijadikan media untuk berekspresi oleh seniman, yang berbeda satu sama lainnya karena pengalaman dan kerjasama dengan bahan bagi setiap seniman tentu tidak sama. Ekspresi menurut kamus Umum Bahasa Indonesia adalah : "Pengungkapan atau proses menyatakan (yaitu memperlihatkan atau menyatakan maksud, gagasan, perasaan, dsb" (Moeliono, 1998: 223). Seniman disebut pula perupa atau creator, selalu bergelut dengan kreativitas melalui eksperimen, inspirasi dan inovasi. Dalam pergaulan yang lama antara seniman dan bahan, umumnya akan terjadi suatu pengenalan yang terus menerus yang akhirnya menyatukan seniman dan bahannya. Seniman begitu mengenal bahannya, sehingga ia telah mengetahui apa yang dapat seniman capai dengan bahan tersebut dan bagaimana cara yang paling tepat untuk memanipulasi bahan dan mewujudkan suatu ide dan teknik tidak lagi terjadi tarik-menarik, melainkan suatu kerja sama akrab yang akan menghasilkan karya akhir yang diinginkan. Inilah yang akan melahirkan apa yang disebut sebagai "sentuhan-sentuhan pribadi seorang seniman", yang berbeda satu sama lainnya karena pengalaman dan kerja dengan bahan bagi setiap seniman tentu tidak sama. Timbul Raharjo mengatakan bahwa sebuah karya seni merupakan cerminan jiwa penciptanya. Bentuk-bentuk karya seni keramik itu merupakan ungkapan yang timbul dan tumbuh dalam batin sang seniman (Raharjo, 2001:4). Sedangkan Hildawati Soemantri mengatakan bahwa pendekatan keramik harus mulai dari pengetahuan dasar mengenai bahan tanah liat, serta menguasai skill teknis. Hanya setelah itulah dia dapat menuju ketingkat berikutnya (Soemantri via Carla Biapoen, 2005: 83).

Metode Pendekatan dalam penciptaan karya ini melalui estetis yaitu 
metode yang digunakan mengacu pada nilainilai estetis yang terkandung dalam seni rupa, sehingga mempengaruhi seni tesebut seperti garis (line), bentuk (shape), warna (color), tekstur (texture) dan lain-lain (Feldman, 1967). Pendekatan estetis adalah cara pandang yang bertolak dari segi polapola artistik untuk membangun pemahaman atas unsur-unsur seni rupa. Estetik adalah tujuan utama dalam penciptaan karya yang bersumber inspirasi dari food porn ini. Ketentuan basic desain yang telah dipelajari dalam studi seni kriya sebagai bagian bawah sadar yang secara sepontan keluar menjadi kaidah baku dalam melakukan penciptaan seni kriya, yang dimulai dari sketsa sampai pada tahap penyelesaian. Perjalanan panjang itulah yang dimaksud dengan proses artistik dalam merekonstruksi sebuah sumber insprasi sampai perwujudan karya yang dinikmati di ruang pamer (Dharsono, 2004).

Metode penciptaan adalah cara yang dipakai dalam pengumpulan data di lapangan maupun studi lainnya guna mendukung kelancaran proses penciptaan karya seni (Gustami, 2007: 329). Eksplorasi yaitu proses pencarian bentuk-bentuk melalui sketsa yang akan dipilih untuk pembuatan karya yang akan diciptakan. Perwujudan yaitu proses pembuatan karya seni yang dimulai dari persiapan mengolah bahan, menyiapkan alat-alat, proses pembentukan, dan pembakaran.

Dalam membedah sebuah karya selain teori penciptaan yang digunakan untuk membedah proses yang dilakukan dalam mewujudkan karya seni, penulis juga menggunakan teori yang digunakan untuk membedah konsep. Dalam pembedahan konsep ini penulis menggunakan teori dari Dr. Hugo Heyman yang berjudul "Art and Synestesia : in research of the synesthetic experiende" dalam konferensi yang diadakan di Universitas de Almeria, Spanyol. Hugo menyatakan bahwa :

"Life is continuous synesthetic experience, seeing, smelling, touching, hearing and tasting-the world discloses itself to us through the senses. The neurological condition, 'synesthesia' is a responding to a stimulus of one sense modality with sensations which belong to another sense modality. In 1883, Sir Francis Galton made the first scientific report, describing the experiences of synesthetes, (he called them 'seers'). Now we know that the synesthetic experience of a synesthete is a real and concrete sensory phenomenon. Synesthesia seems to be a natural form of virtual reality. The following forms of synsthesia(s) are showing how many variations in normal brain functioon are possible."

Hugo Heyman juga membuat sebuah diagram bagaimana proses synesthetic berlangsung yang merupakan modifikasi diagram dari Gino Casagrande (2004).

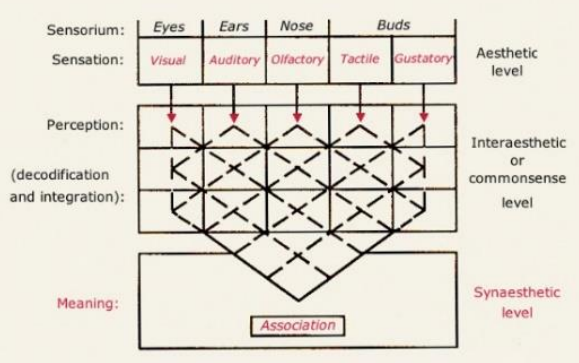

Gambar. 1 Diagram Synesthetic process oleh Hugo Heyman 2005

(Sumber : www.doctorhugo.org)

Proses penciptaan karya ilmiah ini diperlukan data acuan mengenai Food porn dan coral untuk memperoleh keakuratan dan pembuktian adanya keterkaitan dengan konsep karya sebagai bahan referensi. Data diperoleh melalui media majalah, internet, dan buku-buku terkait. Sebagai berikut: 


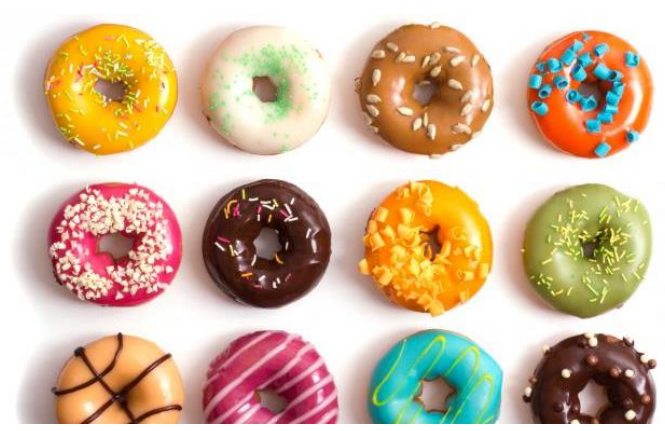

Gambar. 2 Donat menajdi objek yang dipilih sebagai makanan mainstream yang kerap diunggah ke social media.

(Sumber :

http://assets.wh.cdnds.net/images/615/doughnuts_s election_medium_4x3.jpg, 7 Januari 2017)

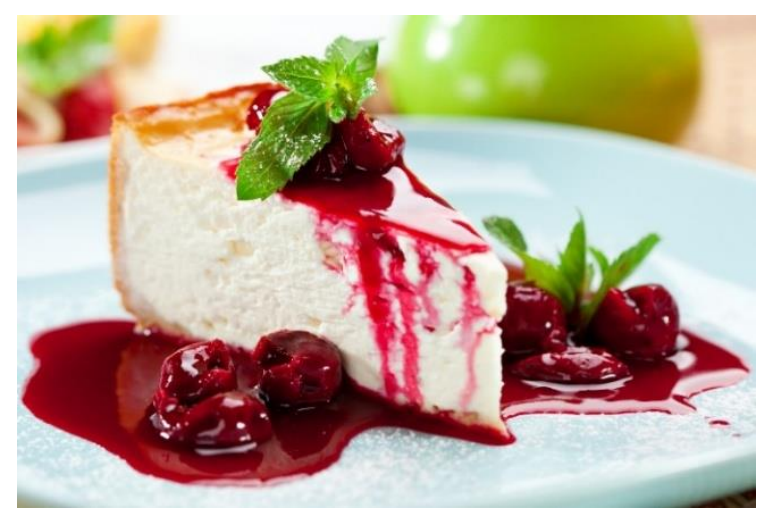

Gambar. 3 Cheese cake yang difoto dengan begitu cantik, sehingga dapat menggugah rasa lapar. (Sumber : http://piazzetta.ca/wpcontent/uploads/2016/06/CHEESE-CAKE.jpg, 7 Januari 2017 )

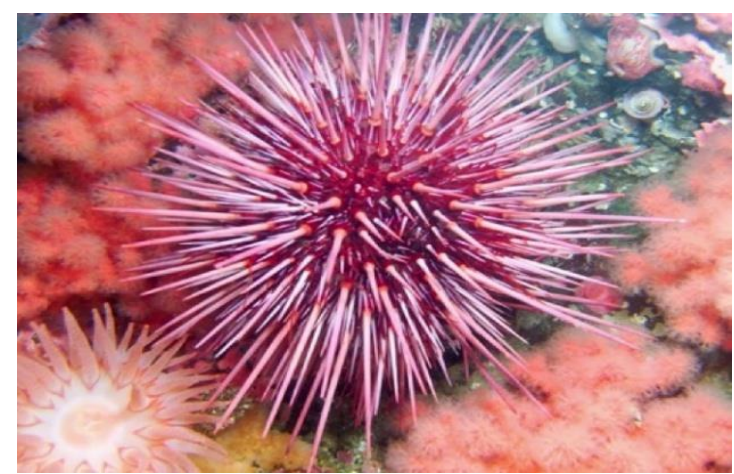

Gambar. 4 Bulu babi yang berada didalam laut, spesiesnya tidak hanya berwarna hitam, namun juga ada putih, merah, dan kuning. Biasanya bagian dalamnya berwarna kekuningan dimakan sebagai tambahan toping pada susi dan masakan ekstream lainnya.

(Sumber : http://assets.kidnesia.com/media_ kidnesia/article_image/cover/original/10360-caramengobati-bila-tertusuk-bulu-babi.jpg, 7 Januari 2017)

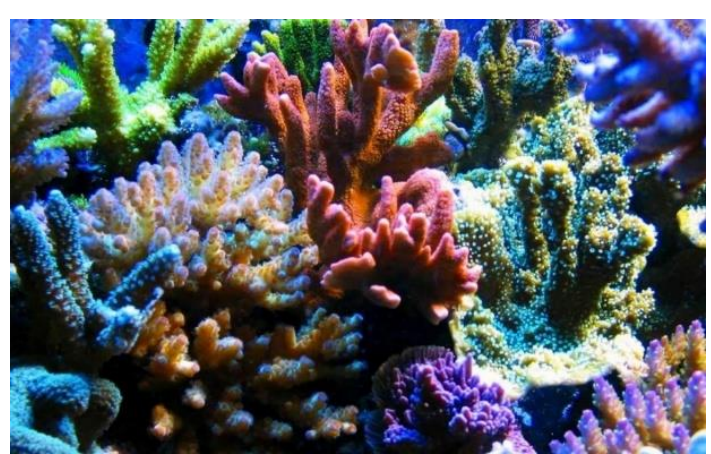

Gambar. 5 Bentuk-bentuk coral yang akan diadopsi untuk menjadi bagian dari ekspresi pendekorasian dalam keramik.

(Sumber :

http://www.sz0931.com/data/out/20/52649195-

coral-wallpaper.jpg, 7 Januari 2016)

\section{Berikut ini adalah perencanaan} karya yang akan diawali dengan pembuatan sketsa terpilih:

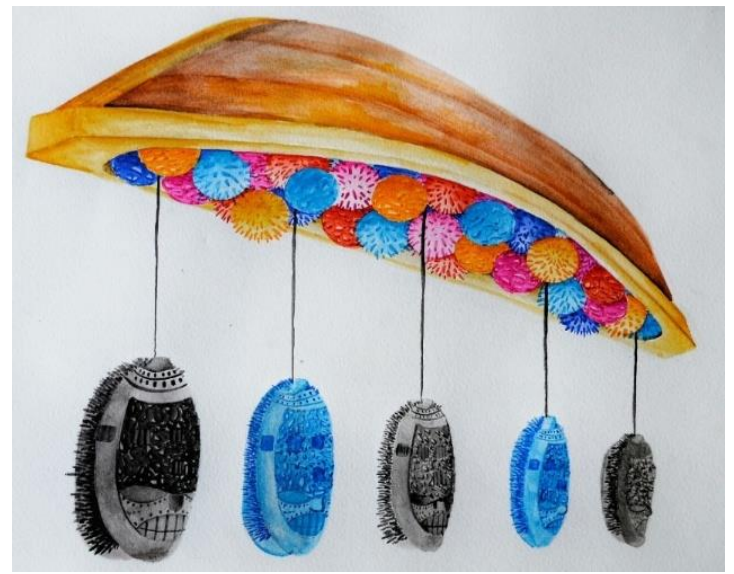

Gambar. 6 Sketsa I Gambar Display

(Sketsa : Dyah Retno Fitriani)

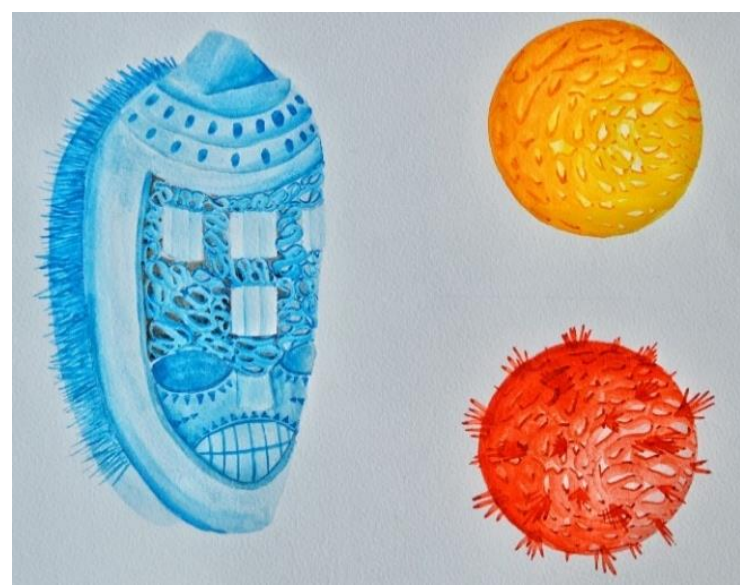

Gambar. 7 Sketsa I Gambar detail (Sketsa : Dyah Retno Fitriani) 


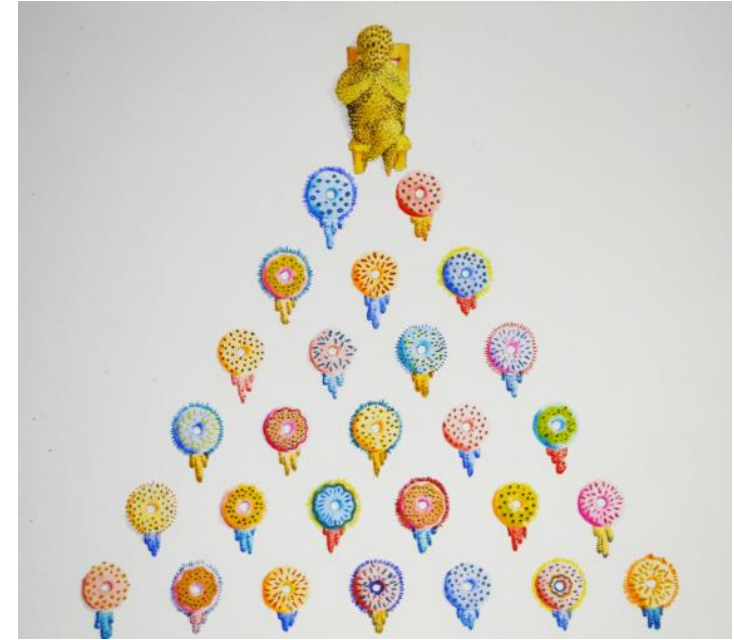

Gambar. 8 Sketsa II Gambar Display (Sketsa : Dyah Retbo Fitriani)

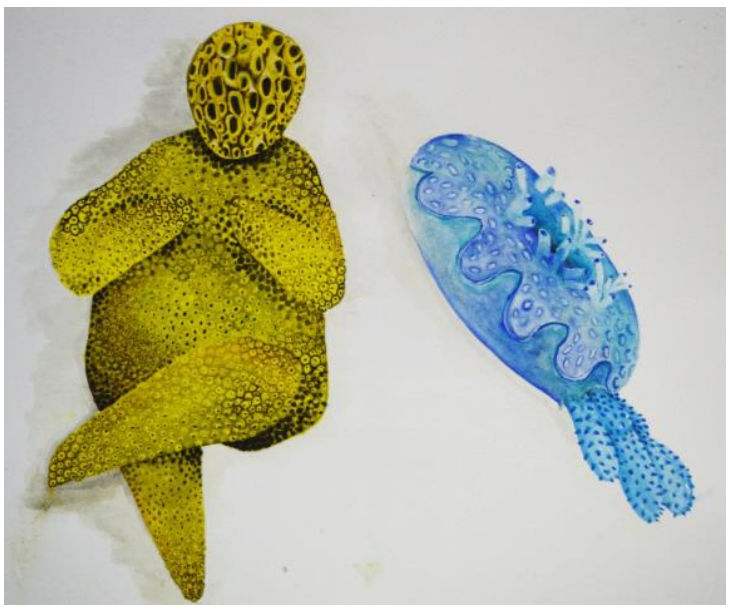

Gambar. 9 Sketsa II Gambar Detail (Sketsa : Dyah Retno Ftriani)

Bahan baku utama untuk mengerjakan karya ilmiah menggunakan bahan utama tanah liat jenis stoneware yaitu tanah liat Sukabumi dan Pacitan berwarna coklat kemerahan pada saat keadaan basah, bahan lainnya berupa glasir dan gypsum. Alat yang mendukung dan sesuai dengan pengerjaan karya ilmiah ini yaitu pisau, satu set butsir, plastic, triplek, spray gun, spon, senar pemotong, dan lain-lain.

Teknik hand building dan slip casting digunakan dalam pembuatan karya karya seni keramik ini dan beberapa teknik dekorasi diantaranya teknik krawang dan teknik pilin. Ada beberapa tahap yang harus di kerjakan dalam prmbuatan karya karya seni keramik ini diantaranya yaitu: Tahap awal pengolahan bahan, tahap kedua model dan cetakan, tahap ketiga pembentukan, tahap keempat pengeringan, tahap kelima pembakaran biskuit sampai suhu $800^{\circ} \mathrm{C}$, tahap keenam pengglasiran, dan tahap ketujuh pembakaran glasir mencapai suhu $1200^{\circ} \mathrm{C}$. (Billington, 1974).

\section{Hasil dan Pembahasan}

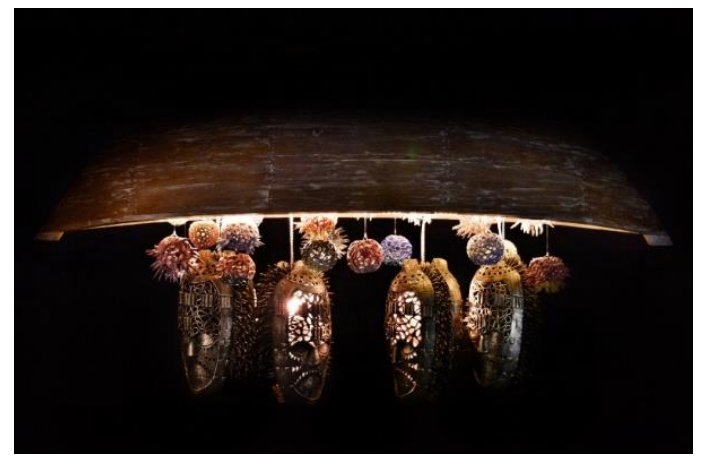

Gambar. 10 Karya I Judul : Ancient, Ukuran : Variable Dimention, Teknik : Slip Casting, Krawang, Coil, Bahan : Sukabumi Stoneware, Wood, Finishing : Glasir, Suhu Bakar : $1200^{\circ} \mathrm{C}$, (Foto : Sebastian Advent, 2017)

Ancient yang berarti kuno adalah sebuah judul untuk mewakili karya seni ini yang memang ingin menampilkan kekunoannya dalam segi konsep dan visual. Secara formalis, karya seni ini mempresentasikan bentuk kapal, perwujudan bola berduri sebagai representasi dari bulu babi, dan topeng yang menggambarkan nenek moyang. Dari segi fungsionil karya seni ini dapat difungsikan sebagai lampung gantung yang dapat diaplikasikan didalam elemen interior.

Dari jaman kuno dahulu, banyak mitos dan cerita-cerita yang mengisahkan bahwa nenek moyang kita adalahseorang pelaut. Bahkan cerita tersebut sempat menjadi lirik lagu anak-anak yang berlirik "nenek moyangku seorang pelaut, gemar mengarung luas samudra, menerjang ombak tiada takut, menempuh badai sudah biasa", penulis meyakini bahwa adanya cerita hingga dijadikan sebuah lagumerupakan 
bahasa pengungkapan yang dipengaruhi dengan prekondisi keadaan di Indonesia yang merupakan negara kelautan. Indonesia mempunyai keadaan alam yang indah, dari gunung, sawah, pantai hingga dasar laut yang menyimpan keanekaragaman dan kekayaan coral beserta biota lautnya. Salah satu biota laut yang mencoba penulis angkat dalam karya seni ini adalah babi laut yang semakin mengkhawatirkan keadaanya karena banyak dieksploitasi, diambil untuk dijadikan makanan di restoran-restoran.

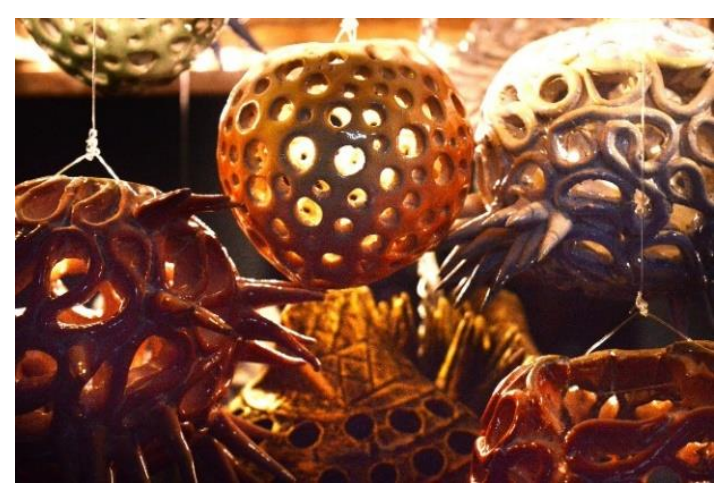

Gambar. 11 Detail karya Ancient (Foto : Sebastian Advent, 2017)

Memang tidak banyak yang menyadari akan keberadaan bulu babi sekarang ini, namun upaya adanya konservasi juga harus dilakukan dan sudah mulai dilakukan oleh orang-orang yang peduli dengan kehidupan laut. Bulu babi yang dijadikan makanan merupakan hal ekstream oleh beberapa orang dan sempat menjadi perbincangan yang viral di dunia maya, makanan ini kerap difoto dengan angle yang luar biasa baiknya lalu diunggah dan masuk menjadi salah satu bagian fenomena food porn.

Pengangkatan wacana-wacana diatas merupakan ide baru dalam pmbuatan karya penulis yang juga merupakan sebuah keprihatinan kini coral dan biota laut banyak yang rusak dan tak terjaga, juga mnjadi sebuah representasi dari sudut pemikiran penulis dalam memvisualisasikan konsep yang berasal dari wacana yang ada. Pada intinya, penulis ingin menyampaikan bahwa pada cerita kuno nenek moyang kita adalahseorang pelaut, kelautan Indonesia dikatakan sebagai satu yang paling indah di dunia, dan kita harus tetap menjaganya jangan sampai hal ini hanya akan menjadi cerita belaka seperti cerita-cerita kuno yang telah lalu.

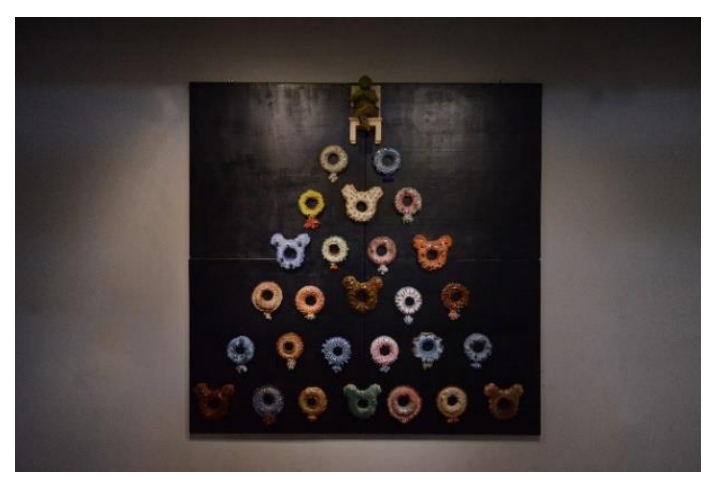

Gambar. 12 Karya II Judul : Rakus, Ukuran : $210 \times 240$ x $20 \mathrm{~cm}$, Teknik : Slip Casting, Pinch, Coil, Bahan : Sukabumi dan Pacitan Stoneware, Wood, Finishing: Glasir, Suhu Bakar : $1200^{\circ}$ C, (Foto : Dyah Retno Fitriani, 2017)

Anak muda jaman ini sedang digandrungi berfoto, akibat adanya konvergensi media yang didukung dengan munculnya sosial media yang baru seperti instagram menjadi wahana yang tepat bagi mereka untuk saling melihat post, berbagi foto kegiatan bahkan cafe dan makanan yang sedang mereka kunjungi. Kegiatan seperti ini justru terlihat seperti ajang pencarian identitas, siapa yang memiliki banyak followers dan lovers lalu akan menjadi idola atau yang dikenal sebagai sosmed seleb walaupun mereka berasal dari kalangan yang biasa saja. Berbagai hashtag dikreasikan, salah satunya adalah hashtag yang bertajuk food porn, bukan hanya makanan fotogenic yang diupload namun 
kini merambah ke video singkat bagaimana cara memasak dan menyajikan makanan agar terlihat indah.

Dalam gejala mainstream, seringkali yang menjadi bagian dari food porn adalah makanan junk food, salah satunya yang paling mainstream adalah donat. Semenjak kemunculannya, diberbagai cafe yang memperjual belikan donat baik di outletnya atau di mall selalu dipenuhi dengan anak muda, berbagai versi alasan muncul mulai dari hangout hingga untuk mencari identitas diri agar terlihat keren. Tempat-tempat semacam ini menjadi incaran para kaum urban, bukan hanya karena makanannya, namun juga artistik tempat dan style mereka.

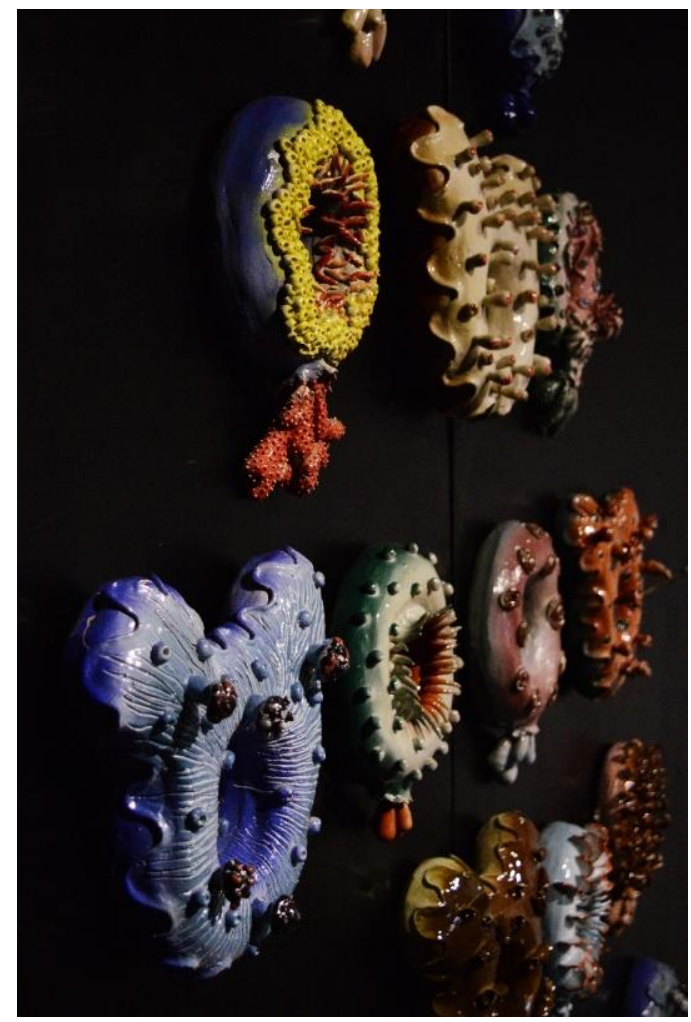

Gambar. 13 Detail karya Rakus yang memvisualisasikan bentuk donat dengan dekorasi coral (Foto : Sebastian Advent, 2017)

Dalam karya yang bejudul rakus ini, penulis mempresentasikan bentuk donat dan orang yang sedang duduk sebagai representasi dari kaum urban masa kini. Secara formalis terdapat bentuk donat dengan motif dekorasi yang mengacu pada bentuk-bentuk coral yang juga untuk mengingatkan akan kelautan Indonesia. Pada tekstur figur manusia, penulis mewujudkannya dalam bentuk tekstur yang menyerupai trypophobia. Hal ini juga didukung oleh teori art and synesthesia dari Hugo Heyman yang dalam pengaplikasiannya dalam katya seni ini berupa sensasi bahwa sebuah karya seni yang dapat dilihat oleh indera pengelihatan juga dapat mempengaruhi cara kerja indera yang lain seperti indera peraba.

Dalam kasus orang-orang yang terkena trypophobia, tekstur yang diwujudkan dalam karya ini bisa menundang berbagai reaksi emosional seperti takut hingga reaksi yang menyebabkan gatal, keringat dingin, bahkan pingsan. Selanjutnya karya ini dengan tinjuan teori tersebut diharapkan tidak hanya mampu memberikan siguhan estetis, namun juga dapat difungsikan sebagai media terapi pada orang yang terkena trypophobia.

\section{PENUTUP}

Sebuah karya seni dapat terlahir dari ketertarikan, kesukaan, kecintaan akan sesuatu hal, yang sifatnya tidak mutlak, dan setiap orang relatif berbeda-beda. Hal tersebutlah yang terkadang menjadi sebuah kegelisahan yang kemudian menjadi ide atau gagasan untuk melahirkan sebuah karya seni. Meskipun ide dari sesuatu hal yang sama, namun karya yang diciptakan belum tentu sama karena setiap orang juga memiliki imajinasi, pengamatan, dan pola berfikir yang berbeda-beda.

Sebuah karya seni dapat hadir dengan berlandaskan pada kegelisahan, wacana, dan keestetisan bentuk dari suatu benda. Dalam penciptaan karya seni ini, 
penulis mengangkat berbagai wacana mengenai food porn, keadaan kelautan Indonesia serta konsep-konsep yang dieksplorasi untuk divisualkan menjadi karya keramik ekspresi ini. Dengan menerapkan kasus mainstream seperti aktivitas kaum urban yang kerapkali mengunggah apa yang mereka lakukan, seperti halnya makan makanan junk food dalam hal ini penulis mengangkat bentuk donat hingga cerita kuno yang menceritakan bahwa nenek moyang kita adalah seorang pelaut, eksploitasi bulu babi dan keadaan maritim yang kurang terjaga merupakan refleksi mengenai fenomena yang ada yang kemudian akan diekspresikan menjadi karya seni ini.

Proses pembuatan karya ini, menggunakan tanah stoneware Sukabumi dan Pacitan yang diolah dengan menambahakan waterglass agar tanah cepat kering. Proses pembentukan dilakukan dengan slip casting dan pinch. Sedangkan pendekorasian menggunakan teknik krawang dan teknik coil. Penggunaan teknik hand building merupakan sebuah teknik yang memiliki craftmanship yang tinggi, karena membutuhkan ketelatenan an kesabaran. Namun teknik seperti itulah yang semakin mendekatkan sehingga tercipta keintiman antara perupa dan karya yang dibuat. Setelah proses pembentukan selesai dilakukan tahap pengeringan dengan cara diangin-anginkan. Kemudian bodi yang sudah kering, dibakar biskuit dengan menggunakan tungku gas hingga suhu $800^{\circ}$ C. Setelah itu dilakukan proses pengglasiran dengan teknik semprot lalu dibakar dengan suhu $1200^{\circ}$ C. Dalam proses pembuatan karya ini ada beberapa kendala dalam pembuatan karya, yaitu bodi keramik yang retak pada saat proses pengeringan yang dikarenakan bahan baku tanah stoneware cair yang digunakan untuk mencetak terlalu banyak pasir. Kendala tersebut menjadi sebuah pembelajaran yang baik untuk dapat berkarya lebih baik lagi di masa yang akan datang.

\section{DAFTAR PUSATAKA}

Astuti, Ambar, (1997), Pengetahuan Keramik, Yogyakarta: Gajah Mada University Press.

Anwar, Anik, (1987), Ringkasan Biology Program $A_{1} \& A_{2}$, Bandung: Ganeca Exact Bandung.

Billington, Dora M, (1974), The Teqnique of Pottery, Rev. ed., London: Bt Basford.

Biological Science Curriculum Study,(1974) Biological Science: An Inquire to Life. Hardcourt, Brace \& World, Inc, Newyork, Chicago, 1963 Limited.

Dharsono Sony Kartika, Nanang Ganda Pratiwi, (2004) Pengantar Estetika, Bandung: Rekayasa Sains.

Feldman, Edmund Burke, (1967), Art, Image and Idea, New Jersy: Prentic-Hall, Inc Englewood Cliffsd.

Gustami SP, (2004), Proses Penciptaan Seni Kriya, Program Penciptaan Seni Pascasarjana, Institut Seni Indonesia Yogyakarta.

ljong, Frans Grubber, (2015), Mikrobiologi Perikanan \& Kelautan, Jakarta: PT. Rineka Cipta.

Moeliono, Anton M., (1998), Kamus Umum Bahasa Indonesia, Jakarta: Balai Pustaka.

Nontji, Anugrah, (2008), Plankton Laut, Jakarta: LIPI Press.

Ocverik, Otto G, (1994), Art Fundamentals Theory \& Praktis, London: Brown \& Benchmark.

Raharjo, Timbul, (2001), Teko dalam Perspektif Seni Keramik, Yogyakarta: Tonil Press. 
Soedarso SP, (2000), Katalogos Pameran Kriya Seni 2000, Galeri Nasional Indonesia Jakarta.

Tim Studio Keramik,(2007), Keramik Buku Teks SMK Petunjuk Praktik Kriya Keramik, Jakarta: Departemen Pendidikan Nasional.

Susanto, Mikke, (2002), Diksi Rupa, Yogyakarta: Kanisius.

\section{Webtografi}

www.myungnaman.uk , 2016

www.vimeo.com/180217504, 2016

http://piazzetta.ca/wpcontent/uploads/2016/06/CHEESE-CAKE.jpg , 7 Januari 2017

https://s-mediacacheak0.pinimg.com/originals/60/81/3e/6 0813e85bfa24f293cd6b7819aedd088.jpg , 7 Januari 2017

http://www.bobobobo.com/baca/wpcontent/uploads/2016/07/image-2.jpg , 7 Januari 2017

www.doctorhugo.org

http://assets.wh.cdnds.net/images/615/do ughnuts_selection_medium_4x3.jpg , 7 Januari 2017 http://www.sz0931.com/data/out/20/5264 9195-coral-wallpaper.jpg , 7 Januari 2016 http://assets.kidnesia.com/media_kidnesia/ article_image/cover/original/10360-caramengobati-bila-tertusuk-bulu-babi.jpg , 7 Januari 2017 